Volume 9, No.3, May - June 2020

International Journal of Advanced Trends in Computer Science and Engineering

Available Online at http://www.warse.org/IJATCSE/static/pdf/file/ijatcs64932020.pdf

https://doi.org/10.30534/ijatcse/2020/64932020

\title{
Expert System of Initial Anamnesis Process of Menstrual Disorders using Certainty Factor Method
}

\author{
Gina Giftia Azmiana Delilah ${ }^{1}$, Cepy Slamet ${ }^{2}$, Diena Rauda Ramdania ${ }^{3}$, Ulfiah Ulfiah ${ }^{4}$, Amalia Mahmudah $^{5}$ \\ ${ }^{1}$ Faculty of Sains and Technology UIN Sunan Gunung Djati Bandung, Indonesia, ginagiftia@uinsgd.ac.id \\ ${ }^{1}$ Doctoral Program of Religious Phyloshopy UIN Sunan Gunung Djati Bandung, Indonesia \\ ${ }^{2}$ Department of Informatics UIN Sunan Gunung Djati Bandung, Indonesia, cepy.lucky@uinsgd.ac.id \\ ${ }^{2}$ Department of ICT Asia E University, Malaysia \\ ${ }^{3}$ Department of Informatics UIN Sunan Gunung Djati Bandung, Indonesia, diena.rauda@uinsgd.ac.id \\ ${ }^{4}$ Department of Psychology UIN Sunan Gunung Djati Bandung, Indonesia, ulfiah@uinsgd.ac.id \\ ${ }^{5}$ Department of Informatics UIN Sunan Gunung Djati Bandung, Indonesia, amalia@gmail.com
}

\begin{abstract}
Anamnesis is a preliminary examination to obtain information about the patient's disease. This process is carried out by the doctor as part of the initial diagnosis of the patient's condition. The purpose of this research is to assist the history process in eliminating the diagnosis of possible diseases from experts by adopting their knowledge into the expert system. The method used in this study is the Certainty Factor method. Fifty test data collected to test this approach. The test results showed 44 data following expert opinion and obtained an accuracy rate of $88 \%$. These results indicate that the expert system is suitable for the early history of menstrual disorders.
\end{abstract}

Key words: Anamnesis, certainty factor, expert system, menstrual disorder.

\section{INTRODUCTION}

Menstruation is characterized by the thickening of the uterine wall (endometrium), which contains blood vessels. If pregnancy does not occur, then the endometrium will decay and come out with blood through the vagina [1-4]. Menstrual health aspects are an essential part of a woman's reproductive health, not only in the field of physical health but also in aspects of mental health, spiritual and social. A person needs to know the pattern, the distance of her menstruation so that he can judge if something unusual happens [3,4]. The average duration of menstruation is five days. In some ca[5,6]ses, menstruation occurs 2-7 days, even more than 15 days. If the blood is more than 15 days, it is considered as a disease outside the menstrual cycle [2,7]. In 2016, it was found out that in general menstrual disorders are experienced by $90 \%$ of women worldwide [8].

Consultation with a specialist is needed to detect menstrual disorders. This initial inspection activity is known as an anamnesis. Complaints raised by patients taken carefully will help a lot in determining the diagnosis of an illness. There are many types of claims raised by a sufferer of the reproductive system and not always complain about menstrual abnormalities so that patience is needed in conducting anamnesis on a patient [9]. The diagnosis of menstrual disorders in women is categorized from mild to severe, including vomiting and nausea, feeling tired/tired, aching under the waist, feeling anxious and tense, as well as headaches and confusion [10].

Several previous studies have realized the importance of ease of diagnosis regarding health care, including jaundice detection system [11], a determination of menstrual disorders using a forward chaining algorithm [12,13], an expert system for diagnosing dysmenorrhea with Naive Bayes [14], an expert system for diagnosing menstrual abnormalities [15], an expert system for diagnosing menstrual delays (Oligomenorrhea) with Bayes [16], an expert system for menstruation diagnostics based on Android [17], and so forth. In this study, an expert system builds to diagnose the anamnesis disturbance process using the Certainty Factor Method inference engine. The reason for using expert systems is because they have proven to be able to solve cases effectively $[18,19]$. The certainty factor is a method that can determine whether a fact is certain or not [20].

\section{CERTAINTY FACTOR}

Certainty Factor method is a method proposed in 1975 by Shortlife and Buchanan to accommodate the uncertainty of the thinking of an expert [6,21,22]. Certainty Factor is a certain measure of a rule or fact. The calculation of the Certainty Factor value is explained in Equation 1 [21,23].

$C F(H, E)=M B(H, E)-M D(H, E)$

(1)

where

CF: the certainty factor in the hypothesis $\mathrm{H}$ due to evidence $\mathrm{E}$ MB: the measure of increased belief in $\mathrm{H}$ due to $\mathrm{E}$ MD: the measure of increased disbelief in $\mathrm{H}$ due to $\mathrm{E}$

$M B[h, e 1]+M B[h, e 2] .(1-M B[h, e 1])$

$M D[h, e 1]+M D[h, e 2] .(1-M D[h, e 1])$ 
$\mathrm{CF}$ value data is taken from the reduction between $\mathrm{MB}$ value and MD value. $\mathrm{CF}$ value data is used for the calculation process between $\mathrm{MB}$ and MD so that the results obtained from the consultation. From the results of interviews and discussions with experts or obstetricians, weight tables for MB and MD values, which can be seen in Table 1 [24].

Table 1: MB and MD Value Range

\begin{tabular}{|c|c|}
\hline Trust & MB/MD \\
\hline Unknown & $0-0.29$ \\
\hline Maybe & $0.3-0.49$ \\
\hline Most Likely & $0.5-0.69$ \\
\hline Almost certainly & $0.7-0.89$ \\
\hline Certainly & $0.9-1.0$ \\
\hline
\end{tabular}

Certainty Factor values are in the range -1 to 1 . Following the confidence level of CF can be seen in Table 2 [24].

Table 2: Level of Confidence $\mathrm{CF}$

\begin{tabular}{|c|c|}
\hline Uncertain Term & CF \\
\hline Definitely not & -1.0 \\
\hline Almost certainly not & -0.8 \\
\hline Probably not & -0.6 \\
\hline Maybe not & -0.4 \\
\hline Unknown & -0.2 to 0.2 \\
\hline Maybe & 0.4 \\
\hline Probably & 0.6 \\
\hline Almost Certainly & 0.8 \\
\hline Definitely & 1.0 \\
\hline
\end{tabular}

\section{METHODOLOGY}

\subsection{Business Modeling}

In constructing an early history of menstrual disorders, an analysis of the current system was carried out by distributing questionnaires to women with 111 respondents, the results of the respondents noted that $68.5 \%$ had menstruation at the age of 12-16 years, and more than $80 \%$ of women had understood the meaning of menstruation scientifically and menstrual disorders themselves, but of 111 women $55.9 \%$ did not know how to manage menstrual disorders and $19.8 \%$ said they did not know at all.

Types of menstrual disorders that women often experience are pain during menstruation or (dysmenorrhea) with a percentage of $30.6 \%$, and the second disorder is irregular menstruation (Oligomenorrhea with a percentage of $13.5 \%$, with the existence of this survey $93.7 \%$ of 111 respondents want a system that can help them know the types of menstrual disorders they are experiencing and how to manage menstrual disorders.

In the system running in the field, the patient must go through a long process when consulting with a doctor, as in Figure 1.
This study simplifies the process of history, taking in a flowchart in Figure 2.

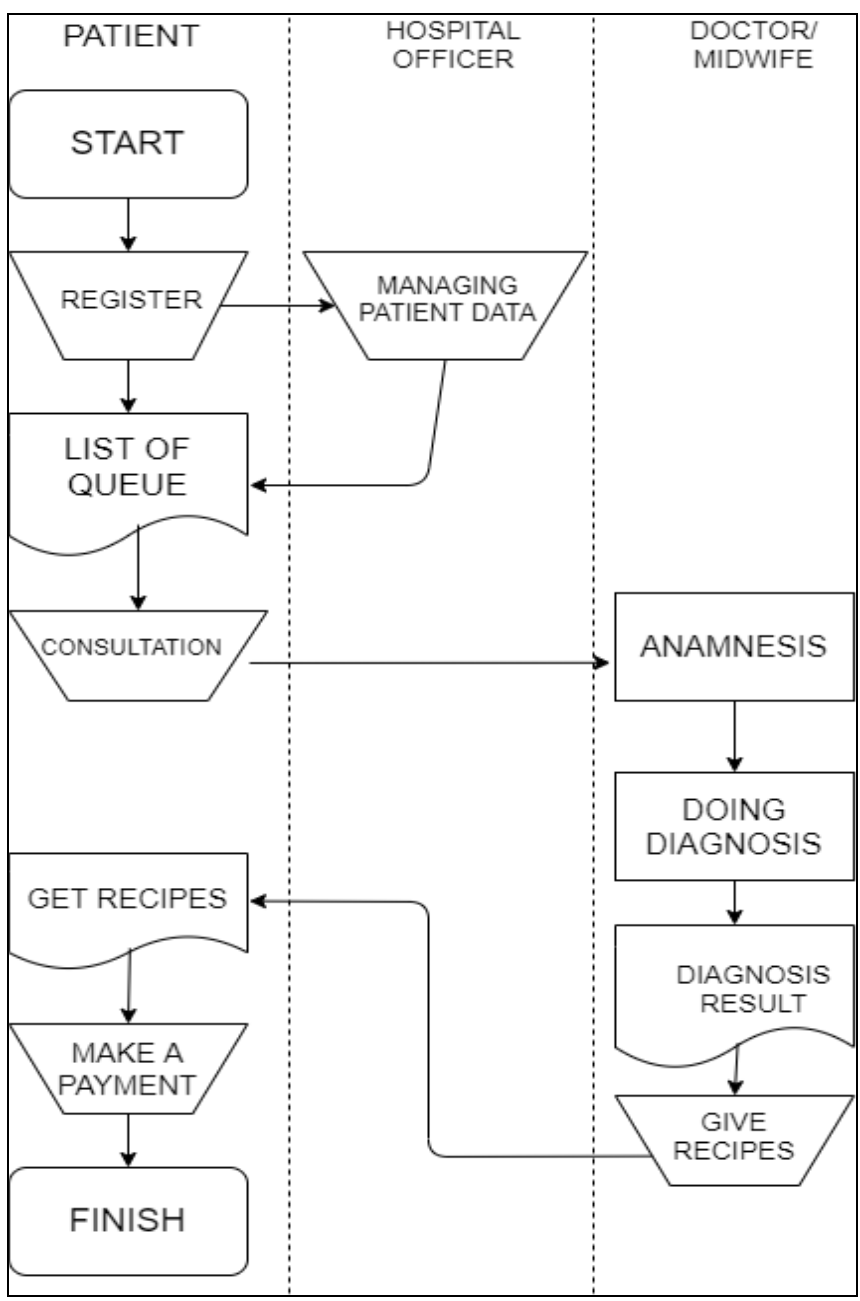

Figure 1: Flow map of the current system

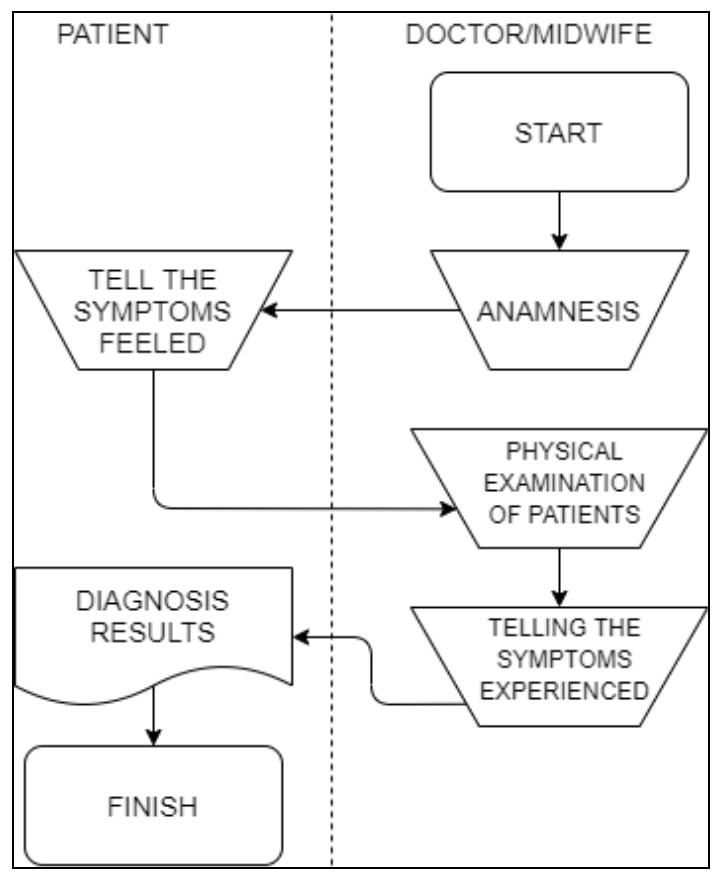

Figure 2: Flowchart of the expert system 


\subsection{Requirement Modeling of the System}

System Requirement Modeling consists of functional requirements and a proposed system to be built, namely an expert system for diagnosing menstrual disorders. Table 3 lists the functional requirements for an expert system for diagnosing menstrual disorders.

Table 3: Functional requirements

\begin{tabular}{|c|c|c|}
\hline ID & Requirement & Explanation \\
\hline AK-F-03 & $\begin{array}{l}\text { Manage data } \\
\text { relations } \\
\text { between } \\
\text { diseases and } \\
\text { symptoms }\end{array}$ & $\begin{array}{l}\text { The software provides facilities } \\
\text { to manage data relations between } \\
\text { conditions and symptoms, } \\
\text { including adding, deleting, and } \\
\text { changing data. }\end{array}$ \\
\hline AK-F-04 & $\begin{array}{l}\text { Display the } \\
\text { consultation } \\
\text { page }\end{array}$ & $\begin{array}{l}\text { The system displays a } \\
\text { consultation page that will be } \\
\text { used by the user or patient by } \\
\text { selecting symptoms that are felt } \\
\text { by showing a checkbox. }\end{array}$ \\
\hline AK-F-05 & $\begin{array}{l}\text { Perform an } \\
\text { initial history } \\
\text { process }\end{array}$ & $\begin{array}{l}\text { The system can process the } \\
\text { initial history by processing the } \\
\text { data needed using the Certainty } \\
\text { Factor method. }\end{array}$ \\
\hline AK-F-06 & $\begin{array}{l}\text { Showing } \\
\text { anamnesis } \\
\text { results }\end{array}$ & $\begin{array}{l}\text { The system can display the } \\
\text { results of anamnesis in the form } \\
\text { of the name of the disturbance } \\
\text { and its handling and also the } \\
\text { most significant percentage of } \\
\text { CF obtained. }\end{array}$ \\
\hline AK-F-07 & $\begin{array}{l}\text { Change the } \\
\text { admin } \\
\text { password }\end{array}$ & $\begin{array}{l}\text { The system can change the old } \\
\text { admin password into a new one }\end{array}$ \\
\hline
\end{tabular}

The history process starts after the user inputs the symptoms he feels into the system. After that, the system will first calculate the MB, and MD values of the first symptom input, the MB and MD values in this first symptom are the MB and MD values that have been given by experts or previous experts. Then, in the second symptom and so on, the MB and MD values in the first symptom become a benchmark for calculating the next $\mathrm{MB}$ and $\mathrm{MD}$ values.

To calculate the MB and MD values in the following symptoms the following formulas 4 and 5 are used

Temporary $M B=$ Old $M B+($ New $M B *(1-$ Old $M B))$

Temporary $M D=$ Old $M D+($ New $M D *(1-$ Old $M D))$

The Old MB and MD values are obtained from the MB and $M D$ values from the first symptom, and the Old MB and MD values are derived from the MB and MD values for the signs that have been given by the first expert. After calculating all the symptoms entered, then the next is to calculate the CF value to get the amount of confidence. The assessment is carried out at this stage to determine the most considerable CF value that will be used as a conclusion. Then, the system will output the type of menstrual disorders along with the percentage of $\mathrm{CF}$ and also recommendations for treatment and treatment that must be met by the user or patient.

Several scenarios were also made to support the development of an expert system of the history of menstrual disorders. Table 4 explains the analysis of various menstrual disorders.

Table 4: Data of Menstrual Disorders

\begin{tabular}{|c|l|}
\hline Code & Disease Name \\
\hline P1 & Pain during menstruation (Dysmenorrhea) \\
\hline P2 & $\begin{array}{l}\text { Extremely long periods of time (Menorrhagia) or } \\
\text { (Heavy Menstrual Bleeding) }\end{array}$ \\
\hline P3 & Irregular Menstruation (Oligomenorrhea \\
\hline P4 & Not having menstruation (Amenorrhea) \\
\hline P5 & More frequent menstruation (Polimenorea) \\
\hline
\end{tabular}

Table 5 describes the analysis of the symptoms of menstrual disorders.

Table 5: Data Symptoms of Menstrual Disorders

\begin{tabular}{|c|l|}
\hline Code & \multicolumn{1}{|c|}{ Name of Symptoms } \\
\hline G1 & Cramping the uterus \\
\hline G2 & Pain that makes you unable to move \\
\hline G3 & Pain takes place early or during menstruation \\
\hline G4 & Pain in the lower back of the foot \\
\hline G5 & Pain in the hip bones, and nausea \\
\hline G6 & Menstruation exceeds the usual days or> 7 days \\
\hline G7 & Changing pads almost every hour \\
\hline G8 & $\begin{array}{l}\text { Excessive menstrual bleeding at night which makes } \\
\text { changing pads more often }\end{array}$ \\
\hline G9 & $\begin{array}{l}\text { excessive blood loss causes anemia, weakness, fatigue, } \\
\text { and shortness of breath }\end{array}$ \\
\hline G10 & There are blood clots that are not normal \\
\hline G11 & Irregular periods so unpredictable \\
\hline G12 & $\begin{array}{l}\text { Within a year only 4-9 menstrual periods, for } \\
\text { menstruation to the next period of more than 35 days }\end{array}$ \\
\hline G13 & Not menstruating at age> =16 \\
\hline G14 & Experiencing mental and emotional stress \\
\hline G15 & $\begin{array}{l}\text { Has menstruated but stopped for three months or more } \\
\text { in a row }\end{array}$ \\
\hline G16 & $\begin{array}{l}\text { For menstruation to the next period is only 2-8 days } \\
\text { apart }\end{array}$ \\
\hline G17 & $\begin{array}{l}\text { Menstrual cycles shorter than 21 days in a regular } \\
\text { pattern }\end{array}$ \\
\hline G18 & $\begin{array}{l}\text { Almost the same amount of bleeding during } \\
\text { menstruation }\end{array}$ \\
\hline
\end{tabular}

After the data and symptoms are obtained, an analysis of disease data is then made as a decision table. The results of the study are presented in Table 6 . 
Table 6: Decision Table

\begin{tabular}{|l|l|l|l|l|l|}
\hline \multicolumn{7}{|c|}{ Disease } \\
\hline G1 & $\sqrt{ }$ & & & & \\
\hline G2 & $\sqrt{ }$ & & & & \\
\hline G3 & $\sqrt{ }$ & & & & \\
\hline G4 & $\sqrt{ }$ & & & & \\
\hline G5 & $\sqrt{ }$ & & & & \\
\hline G6 & & $\sqrt{ }$ & & & \\
\hline G7 & & $\sqrt{ }$ & & & \\
\hline G8 & & $\sqrt{ }$ & & & \\
\hline G9 & & $\sqrt{ }$ & & & \\
\hline G10 & & $\sqrt{ }$ & & & \\
\hline G11 & & & $\sqrt{ }$ & & \\
\hline G12 & & & $\sqrt{ }$ & & \\
\hline G13 & & & & $\sqrt{ }$ & \\
\hline G14 & & & & $\sqrt{ }$ & \\
\hline G15 & & & & $\sqrt{ }$ & \\
\hline G16 & & & & & $\sqrt{ }$ \\
\hline G17 & & & & & $\sqrt{ }$ \\
\hline G18 & & & & & $\sqrt{ }$ \\
\hline
\end{tabular}

MB and MD values in the Certainty Factor in this system were obtained from 3 experts in the field of menstrual disorders. The weight values obtained for $\mathrm{MB}$ and $\mathrm{MD}$ presented in Table 7.

Table 7: Value of MB and MD

\begin{tabular}{|c|c|c|c|c|}
\hline No & $\begin{array}{l}\text { Code of } \\
\text { Disease }\end{array}$ & Code of Symptom & MB & MD \\
\hline \multirow[t]{5}{*}{1} & \multirow[t]{5}{*}{$\mathrm{P} 1$} & G1 & 0.8 & 0.03 \\
\hline & & G2 & 0.9 & 0.01 \\
\hline & & G3 & 0.9 & 0.01 \\
\hline & & G4 & 0.5 & 0.03 \\
\hline & & G5 & 0.7 & 0.02 \\
\hline \multirow[t]{5}{*}{2} & \multirow[t]{5}{*}{$\mathrm{P} 2$} & G6 & 0.9 & 0.01 \\
\hline & & G7 & 0.8 & 0.01 \\
\hline & & G8 & 0.6 & 0.03 \\
\hline & & G9 & 0.7 & 0.01 \\
\hline & & G10 & 0.7 & 0.02 \\
\hline \multirow[t]{2}{*}{3} & \multirow[t]{2}{*}{ P3 } & G11 & 0.9 & 0.01 \\
\hline & & G12 & 0.9 & 0.01 \\
\hline \multirow[t]{3}{*}{4} & \multirow[t]{3}{*}{ P4 } & G13 & 0.8 & 0.02 \\
\hline & & G14 & 0.5 & 0.03 \\
\hline & & G15 & 0.9 & 0.01 \\
\hline \multirow[t]{3}{*}{5} & \multirow[t]{3}{*}{ P5 } & G16 & 0.9 & 0.01 \\
\hline & & G17 & 0.8 & 0.01 \\
\hline & & G18 & 0.8 & 0.01 \\
\hline
\end{tabular}

When the patient feels one symptom, the formula is $\mathrm{CF}=$ MB-MD. For example, when a patient experiences symptoms with the G1 code, then the $\mathrm{MB}$ and $\mathrm{MD}$ values of the symptoms can be seen in table 3.5 , namely 0.8 and 0.03 . And the relationship between disease and symptoms is only in those who have these symptoms only P1. So, the results of the calculation the user is likely to experience the criteria for signs of interference with the code $\mathrm{P} 1$ with a value of $\mathrm{CF}=$ 0.8-0.03 $=0.77$. Another example is when a patient experiences one symptom in each menstrual disorder criteria. The first CF value of each sign must be sought after, then determining the $\mathrm{CF}$ value that is the greatest of each symptom in the disease.If the patient chooses more than one symptom, the method of calculation is combined with other symptoms. For example, users choose four symptoms, namely G1, G2, $\mathrm{G} 3$, and G4. MB and MD values of the symptoms are 0.8 and $0.03,0.9$ and $0.01,0.9$ and $0.01,0.5$ and 0.03 . Here are the calculations.

\section{1st calculation:}

Disease 1: P1; Symptom 1: G1; MB =0.8 MD = 0.03.

Old $\mathrm{MB}=$ Empty $=0$

Old $\mathrm{MD}=$ Empty $=0$

New $\mathrm{MB}=\mathrm{MB}=0.8$

New MD = MD 0.03

Temporary $\mathrm{MB}=$ New $\mathrm{MB}=0.8$

Temporary $\mathrm{MD}=$ New $\mathrm{MD}=0.03$

2nd Calculation:

Old MB $=$ Temporary $\mathrm{MB}=0.8$

Old $\mathrm{MD}=$ Temporary $\mathrm{MD}=0.03$

New $M B=M B=0.9$

New $\mathrm{MD}=\mathrm{MD}=0.01$

Temporary $\mathrm{MB}=\mathrm{Old} \mathrm{MB}+(\mathrm{New} \mathrm{MB} *(1-\mathrm{Old} \mathrm{MB}))=0.98$ Temporary MD $=$ Old MD $+($ New MD * $(1-$ Old MD $))=$ 0.0397

Disease 1: P1; Symptom 2: G2; MB $=0.9 \mathrm{MD}=0.01$.

3rd calculation:

Disease 1: P1; Symptom 3: G3; $\mathrm{MB}=0.9 \mathrm{MD}=0.01$.

Old MB $=$ Temporary MB $=0.98$

Old MD $=$ Temporary MD $=0.0397$

New $\mathrm{MB}=\mathrm{MB}=0.9$

New $M D=M D=0.01$

Temporary $\mathrm{MB}=$ Old $\mathrm{MB}+($ New $\mathrm{MB} *(1-$ Old MB $))=$ 0.998

Temporary $\mathrm{MD}=$ Old $\mathrm{MD}+(\mathrm{New} \mathrm{MD} *(1-$ Old $\mathrm{MD}))=$ 0.0493

\section{4th calculation:}

Old MB = Temporary MB 0.998

Old MD = Temporary MD 0.0493

New $\mathrm{MB}=\mathrm{MB} 0.5$

New MD = MD 0.03

Temporary $\mathrm{MB}=$ Old $\mathrm{MB}+($ New $\mathrm{MB} *(1-$ Old $\mathrm{MB}))=$ 0.999

Temporary $\mathrm{MD}=$ Old $\mathrm{MD}+(\mathrm{New} \mathrm{MD} *(1-$ Old $\mathrm{MD}))=$ 0.0778

Disease 1: P1; Symptom 4: G4; MB =0.5 MD =0.03.

$\mathrm{CF}$ Results = Temporary MD-MD Provisional = $0.999-0.0778=0.9212$

$0.9212 * 100 \%=92.12 \%$ 


\section{TESTING}

In the expert system, we diagnose the functions of the systems using black-box testing. This test observes how the results of system execution through test data and functional checking of the expert system.
System accuracy testing is done to test the level of accuracy of the system created. Calculation results from the system will be compared with the results of manual calculations. Table 8 is the result of testing the accuracy of an expert system diagnosing menstrual disorders.

Table 8: System Accuracy Testing Results

\begin{tabular}{|c|c|c|c|c|c|}
\hline No. & Code of Symptom & Manual Calculation & Calculation by system & Expert & Result \\
\hline 1. & G1, G5, G11, G8 & $\begin{array}{l}\text { Dysmenorrhea } 89.06 \% \text {, } \\
\text { Ooligomenorrhea } 89 \% \text {, } \\
\text { Menorrhagia } 57 \%\end{array}$ & Dysmenorrhea $89.06 \%$ & Dysmenorrhea $89.06 \%$ & $\sqrt{ }$ \\
\hline 2. & G15 & Amenorrhea $89 \%$ & & Amenorrhea $89 \%$ & $\sqrt{ }$ \\
\hline 3. & G7, G6 & Menorrhagia $96.01 \%$ & Menorrhagia $96.01 \%$ & Menorrhagia 96.01 & $\sqrt{i}$ \\
\hline 4. & $\begin{array}{l}\text { G16 } \\
\text { G17 }\end{array}$ & Polimenorea $96.01 \%$ & Polimenorea $96.01 \%$ & Polimenorea $96.01 \%$ & $\sqrt{ }$ \\
\hline 5. & G8, G9 & Menorrhagia $89 \%$ & Menorrhagia $89 \%$ & Menorrhagia $89 \%$ & $\sqrt{ }$ \\
\hline 6. & G2, G3 & Dysmenorrhea $89.06 \%$ & Dysmenorrhea $89.06 \%$ & Dysmenorrhea $89.06 \%$ & $\sqrt{ }$ \\
\hline 7. & G11, G12 & Oligomenorrhea $97.01 \%$ & Oligomenorrhea $97.01 \%$ & Oligomenorrhea $97.01 \%$ & $\sqrt{ }$ \\
\hline 8. & $\begin{array}{l}\text { G11, } \\
\text { G2 }\end{array}$ & $\begin{array}{l}\text { Oligomenorrhea } 89 \% \\
\text { Dysmenorrhea } 89 \%\end{array}$ & Dysmenorrhea $89 \%$ & Dysmenorrhea $89 \%$ & $\mathrm{x}$ \\
\hline 9. & G1 & Dysmenorrhea $77 \%$ & Dysmenorrhea $77 \%$ & Dysmenorrhea $77 \%$ & $\sqrt{ }$ \\
\hline 10. & G14, G2 & $\begin{array}{l}\text { Amenorrhea } 47 \% \\
\text { Dysmenorrhea } 89 \%\end{array}$ & Dysmenorrhea $89 \%$ & Dysmenorrhea $89 \%$ & $\sqrt{ }$ \\
\hline 11. & $\mathrm{G} 1, \mathrm{G} 2$ & Dysmenorrhea $94.03 \%$ & Dysmenorrhea $94.03 \%$ & Dysmenorrhea $94.03 \%$ & $\sqrt{y}$ \\
\hline 12. & G7, G9 & Menorrhagia $92.01 \%$ & Menorrhagia $92.01 \%$ & Menorrhagia $92.01 \%$ & $\sqrt{ }$ \\
\hline 13. & G13, G14 & Amenorrhea $85.06 \%$ & Amenorrhea $85.06 \%$ & Amenorrhea $85.06 \%$ & $\sqrt{ }$ \\
\hline 14. & G5, G10 & Dysmenorrhea $68 \%$ & Dysmenorrhea $68 \%$ & Dysmenorrhea $68 \%$ & $\sqrt{i}$ \\
\hline 15. & G16, G17 & Polimenorea $96.01 \%$ & Polimenorea $96.01 \%$ & Polimenorea $96.01 \%$ & $\sqrt{ }$ \\
\hline 16. & G13 & Amenorrhea 78\% & Amenorrhea $78 \%$ & Amenorrhea 78\% & $\sqrt{ }$ \\
\hline 17. & G1, G2, G11, G12 & $\begin{array}{l}\text { Oligomenorrhea } 97.01 \% \\
\text { Dysmenorrhea } 97.01 \%\end{array}$ & Oligomenorrhea $97.01 \%$ & Oligomenorrhea $97.01 \%$ & $\mathrm{x}$ \\
\hline 18. & G8, G9, G16 & $\begin{array}{l}\text { Polimenorea } 89 \% \\
\text { Dysmenorrhea } 89 \%\end{array}$ & Polimenorea $89 \%$ & Polimenorea $89 \%$ & $\mathrm{x}$ \\
\hline 19. & G4, G9 & $\begin{array}{l}\text { Menorrhagia } 69 \% \\
\text { Dysmenorrhea } 47 \%\end{array}$ & Menorrhagia $69 \%$ & Menorrhagia $69 \%$ & $\sqrt{ }$ \\
\hline 20. & G17 & Polimenorea $79 \%$ & Polimenorea $79 \%$ & Polimenorea $79 \%$ & $\sqrt{ }$ \\
\hline 21. & G15, G16, G1 & $\begin{array}{l}\text { Amenorrhea } 91.03 \% \\
\text { Dysmenorrhea } 89 \%\end{array}$ & Amenorrhea $91.03 \%$ & Amenorrhea $91.03 \%$ & $\sqrt{1}$ \\
\hline 22. & G2, G5 & Dysmenorrhea $94.02 \%$ & Dysmenorrhea $94.02 \%$ & Dysmenorrhea $94.02 \%$ & $\sqrt{ }$ \\
\hline 23. & G7, G8, G9 & Menorrhagia $92.67 \%$ & Menorrhagia $92.67 \%$ & Menorrhagia $92.67 \%$ & $\sqrt{ }$ \\
\hline 24. & G4, G9 & $\begin{array}{l}\text { Menorrhagia } 69 \% \\
\text { Dysmenorrhea } 47 \%\end{array}$ & Menorrhagia 69\% & Menorrhagia $69 \%$ & $\sqrt{1}$ \\
\hline 25. & G11, G12 & Oligomenorrhea $97.01 \%$ & Oligomenorrhea $97.01 \%$ & Oligomenorrhea $97.01 \%$ & $\sqrt{ }$ \\
\hline 26. & G1, G2, G3, G4, G5 & Dysmenorrhea $90.34 \%$ & Dysmenorrhea $90.34 \%$ & Dysmenorrhea $90.34 \%$ & $\sqrt{ }$ \\
\hline 27. & G6, G15 & $\begin{array}{l}\text { Menorrhagia } 89 \% \\
\text { Amenorrhea } 89 \%\end{array}$ & Menorrhagia $89 \%$ & Menorrhagia $89 \%$ & $\mathrm{x}$ \\
\hline 28. & G13, G14 & Amenorrhea $85.06 \%$ & Amenorrhea $85.06 \%$ & Amenorrhea $85.06 \%$ & $\mathrm{x}$ \\
\hline 29. & G12 & Oligomenorrhea $89 \%$ & Oligomenorrhea $89 \%$ & Oligomenorrhea $89 \%$ & $\sqrt{ }$ \\
\hline 30. & $\begin{array}{l}\text { G11, } \\
\text { G12 }\end{array}$ & Oligomenorrhea $97,01 \%$ & Oligomenorrhea $97,01 \%$ & Oligomenorrhea $97,01 \%$ & $\sqrt{ }$ \\
\hline 31. & G8, G9, G16 & $\begin{array}{l}\text { Polimenorea89\% } \\
\text { Dysmenorrhea } 89 \%\end{array}$ & Polimenorea89\% & Polimenorea89\% & $\mathrm{x}$ \\
\hline 32. & G10, G3 & Dysmenorrhea $89 \%$ & Dysmenorrhea $89 \%$ & Dysmenorrhea $89 \%$ & $\sqrt{ }$ \\
\hline
\end{tabular}


Gina Giftia Azmiana Delilah et al., International Journal of Advanced Trends in Computer Science and Engineering, 9(3), May - June 2020, 2906 - 2912

\begin{tabular}{|c|c|c|c|c|c|}
\hline No. & Code of Symptom & Manual Calculation & Calculation by system & Expert & Result \\
\hline & & Menorrhagia $68 \%$ & & & \\
\hline 33. & G7, G9 & Menorrhagia $92.01 \%$ & Menorrhagia $92.01 \%$ & Menorrhagia $92.01 \%$ & $\sqrt{4}$ \\
\hline 34. & G16, G18 & Polimenorea $96.01 \%$ & Polimenorea $96.01 \%$ & Polimenorea $96.01 \%$ & $\sqrt{ }$ \\
\hline 35. & $\begin{array}{l}\text { G14, } \\
\text { G2 }\end{array}$ & Dysmenorrhea $89 \%$ & Dysmenorrhea $89 \%$ & Dysmenorrhea $89 \%$ & $\sqrt{ }$ \\
\hline 36. & G8, G9, G10 & Menorrhagia $91.71 \%$ & Menorrhagia $91.71 \%$ & Menorrhagia $91.71 \%$ & $\sqrt{ }$ \\
\hline 37. & $\mathrm{G} 2, \mathrm{G} 3$ & Dysmenorrhea $89.06 \%$ & Dysmenorrhea $89.06 \%$ & Dysmenorrhea $89.06 \%$ & $\sqrt{ }$ \\
\hline 38. & G3 & Dysmenorrhea $89 \%$ & Dysmenorrhea $89 \%$ & Dysmenorrhea $89 \%$ & $\sqrt{1}$ \\
\hline 39. & G1, G8, G14 & $\begin{array}{l}\text { Dysmenorrhea } 77 \% \\
\text { Menorrhagia } 57 \% \\
\text { Amenorrhea } 47 \%\end{array}$ & Dysmenorrhea 77\% & Dysmenorrhea $77 \%$ & $\sqrt{ }$ \\
\hline 40. & G11, G12 & Oligomenorrhea $97.01 \%$ & Oligomenorrhea $97.01 \%$ & Oligomenorrhea $97.01 \%$ & $\sqrt{1}$ \\
\hline 41. & G17, G18 & Polimenorea94.01\% & Polimenorea94.01\% & Polimenorea94.01\% & $\sqrt{ }$ \\
\hline 42. & G7, G8 & Menorrhagia $88.03 \%$ & Menorrhagia $88.03 \%$ & Menorrhagia $88.03 \%$ & $\sqrt{ }$ \\
\hline 43. & G4, G2 & Dysmenorrhea $91.03 \%$ & Dysmenorrhea $91.03 \%$ & Dysmenorrhea $91.03 \%$ & $\sqrt{ }$ \\
\hline 44. & G14, G16, G17 & Polimenorea $96.01 \%$ & Polimenorea $96.01 \%$ & Polimenorea96.01\% & $\sqrt{ }$ \\
\hline 45. & G12, G13 & Oligomenorrhea $89 \%$ & Oligomenorrhea 89 & Oligomenorrhea $89 \%$ & $\sqrt{ }$ \\
\hline 46. & G1, G10 & Dysmenorrhea $77 \%$ & Dysmenorrhea $77 \%$ & Dysmenorrhea $77 \%$ & $\sqrt{ }$ \\
\hline 47. & G11, G12 & Oligomenorrhea $97.01 \%$ & Oligomenorrhea $97.01 \%$ & Oligomenorrhea $97.01 \%$ & $\sqrt{ }$ \\
\hline 48. & G1, G2, G3, G4, G5 & Dysmenorrhea $90.34 \%$ & Dysmenorrhea $90.34 \%$ & Dysmenorrhea $90.34 \%$ & $\sqrt{ }$ \\
\hline 49. & G2, G3 & Dysmenorrhea $89.06 \%$ & Dysmenorrhea $89.06 \%$ & Dysmenorrhea $89.06 \%$ & $\sqrt{ }$ \\
\hline 50. & G6, G15 & $\begin{array}{l}\text { Menorrhagia } 89 \% \\
\text { Amenorrhea } 89 \%\end{array}$ & Menorrhagia $89 \%$ & Menorrhagia $89 \%$ & $\mathrm{x}$ \\
\hline
\end{tabular}

System accuracy testing is carried out according to the following formula 6 .

Accuracy Value $=$

(appropriate amount/number of cases) x 100\%

Based on testing as many as 50 data, there are 6 cases that have had an incompatible execution between manual testing and system testing. This is because, in the manual calculation, there are two symptoms, while the results obtained from the system and experts mention one symptom. So the 6 cases are considered not suitable. The system accuracy values obtained are as follows:

Accuracy Value $=(44 / 50) \times 100 \%=88 \%$

\section{CONCLUSION}

An expert system has been built that applies certainty factors to analyze the history of menstrual symptoms. The study refers to 3 experts who are experts in the field of menstrual disorders. Based on 50 tests, 44 data were obtained according to manual and system calculations. The accuracy value obtained for this system is $88 \%$. This shows that the expert system of anemnesa process early menstrual disorders can run well according to expert diagnosis. The system built is suitable for use in the initial process when consulting before meeting with experts or obstetricians. In the future, more disturbance data that can be felt can be added to produce a better system.

\section{REFERENCES}

[1] Pediatric Clinic Advisor 2007 Menstrual Cycle: An Overview

[2] HealthEngine 2006 Menstruation (period or menstrual cycle)

[3] Maybin J A and Critchley H O D 2015 Menstrual physiology: Implications for endometrial pathology and beyond Hum. Reprod. Update 21 748-61 https://doi.org/10.1093/humupd/dmv038

[4] Sinaga E, Saribanon N, Sa' adah N, Salamah U, Murti Y A, Trisnamiati A and Lorita S 2017 Manajemen Kesehatan Menstruasi (Universitas Nasional)

[5] Krause P, Clark D, Krause P and Clark D 1993 The Certainty Factor Model Representing Uncertain Knowledge

[6] Heckerman D E and Shortliffe E H 1992 From certainty factors to belief networks Artif. Intell. Med.

[7] Anon Palmitoyl-CoA - an overview | ScienceDirect Topics

[8] Larasati T and Alatas F 2016 Dismenore Primer dan Faktor Risiko Dismenore Primer pada Remaja Majority 5 79-84

[9] Gleadle J 2007 Anamnesis dan Pemeriksaan fisik Airlangga. Surabaya 
[10] Negriff S, Dorn L D, Hillman J B and Huang B 2009 The measurement of menstrual symptoms: Factor structure of the menstrual symptom questionnaire in adolescent girls J. Health Psychol. 14 899-908

[11] Raju R and Azzemi N N M 2019 Jaundice detection system Int. J. Adv. Trends Comput. Sci. Eng. 8 $127-31$

https://doi.org/10.30534/ijatcse/2019/2581.52019

[12] Maulina D, Hadian N, Astuti Y and Hidayat T 2019 Penerapan Metode Forward Chaining Pada Sistem Pakar Menentukan Hukum Darah Wanita SENSITIf: Seminar Nasional Sistem Informasi dan Teknologi Informasi pp 629-42

[13] Astuti T B and Utomo F S 2016 Sistem Pakar Diagnosis Gangguan Menstruasi Berbasis Web Service dengan Metode Forward Chaining Isbn 23-4

[14] Nurfarianti Y, Tursina T and Sukamto A S Sistem Pakar untuk Diagnosis Dismenore Menggunakan Metode Naive Bayes JUSTIN (Jurnal Sist. dan Teknol. Informasi) 4 45-50

[15] Yusuf C R M, Fatimah D D S and Damiri D J 2014 Perancangan Sistem Pakar untuk Diagnosis Penyakit Amenorea dengan Menggunakan Metode Expert System Development Life Cycle J. Algoritm. 11 220-9 https://doi.org/10.33364/algoritma/v.11-2.220

[16] Arum V R 2015 Hubungan Status Gizi dengan Kejadian Oligomenore pada Sisiwi di SMK PERINTIS 29 UNGARAN Semarang DIV Kebidanan STIKES Ngudi Waluyo Ung.

[17] Palupi R T 2013 Aplikasi Sistem Pakar Mendiagnosa Gangguan Pada Menstruasi Berbasis Android

[18] Gan G W, Ong J P N and De Guzman M D M 2019 An expert system for a broadcasting network Int. J. Adv. Trends Comput. Sci. Eng. 8 683-8 https://doi.org/10.30534/ijatcse/2019/55832019

[19] Guanzon J S, Caberte C N and Dela Rosa J G P 2019 An expert system optimization model for desktop computers Int. J. Adv. Trends Comput. Sci. Eng. 8 676-82 https://doi.org/10.30534/ijatcse/2019/54832019

[20] Then S, Tursina T and Sastypratiwi H Implementasi Metode Certainty Factor Dalam Mendiagnosa Penyakit Kulit J. Sist. dan Teknol. Inf. 4 11-5

[21] Roventa E and Spircu T 2009 Certainty factors theory Stud. Fuzziness Soft Comput. 227 153-60

[22] Heckerman D 2016 The Certainty-Factor Model *

[23] Munandar T A, Suherman and Sumiati 2012 The Use of Certainty Factor with Multiple Rules for Diagnosing Internal Disease ijaiem 1 58-64

[24] Abidin R J, Kaffah F M, Khaerunisa P, Dauni P and Saputra M I N 2019 Sleep disorder diagnosis expert system using certainty factor method J. Phys. Conf. Ser. 1402

https://doi.org/10.1088/1742-6596/1402/6/066058 